\title{
Pratiques
}

Linguistique, littérature, didactique

183-184| 2019

oralité, littératie

\section{Culture écrite}

Jean-Marie Privat

\section{(2) OpenEdition}

Journals

Édition électronique

URL : http://journals.openedition.org/pratiques/6747

DOI : $10.4000 /$ pratiques. 6747

ISSN : 2425-2042

\section{Éditeur}

Centre de recherche sur les médiations (CREM)

Référence électronique

Jean-Marie Privat, «Culture écrite », Pratiques [En ligne], 183-184 | 2019, mis en ligne le 30 décembre 2019, consulté le 10 octobre 2020. URL : http://journals.openedition.org/pratiques/6747 ; DOI : https://doi.org/10.4000/pratiques.6747

Ce document a été généré automatiquement le 10 octobre 2020

(c) Tous droits réservés 


\title{
Culture écrite
}

\author{
Jean-Marie Privat
}

1 L'histoire de la culture écrite est celle d'une emprise toujours plus grande sur les cultures orales premières. L'empire de l'écrit implique toutefois de ne sous-estimer ni la nostalgie des oralités ni la présence latente des voix dans la littérature écrite. La culture écrite doit aussi être considérée dans ses caractéristiques propres (visualisation, mémorisation, objectivation, spatialisation du langage, etc.) et dans ses différentes manifestations (le clavier, l'écrivain, la main le livre, la bibliothèque, l'Académie, etc.). C'est dans ce cas que l'on parle plutôt de littératie comme d'un système socio-sémiotique complexe qui engage des pratiques, des agents et des valeurs. Le scriptocentrisme est d'un point de vue épistémologique l'angle acritique de la culture écrite/littératie.

\section{AUTEUR}

\section{JEAN-MARIE PRIVAT}

Université de Lorraine, Crem, F-57000 Metz, France 